\title{
PRINCIPLES OF ENFORCEMENT PROCEEDINGS
}

\section{Liudmyla Ostafiichuk ${ }^{1}$}

DOI: https://doi.org/10.30525/978-9934-588-53-2-40

Abstract. The purpose of the work is to analyze the legislative regulation of the list of principles of enforcement proceedings in Art. 2 of the Law of Ukraine "On Enforcement Proceedings" and Art. 4 Law of Ukraine "On Bodies and Persons Engaged in the Enforcement of Judgments and Decisions of Other Bodies" as a dynamic legal regulations, which are aimed at quality organization of enforcement of decisions of courts, other bodies and persons, disclosure of their content.

The reseach methodological basis is a set of general methodological principles and modern methods of scientific knowledge, the use of which is based on a systemic approach, the basis of which is the consideration of the principles of enforcement proceedings as a system that is constantly evolving and filled with new principles and substantive elements. We have used the general scientific dialectical method, classification and clustering, functional method, descriptive method as well as the following search principles like truth, fairness, concrete and logical methods, analysis, synthesis and comparison.

We have found that most of the principles are as multifaceted and regulate enforcement proceeding and determine the legal status of officials responsible for enforcement. Proved feasibility of unification and consolidation in a normative act by analogy with Recommendation Rec (2003) 17 “On compulsory implementation", which is also offered in the article. 2 authors of the Draft Law "On Enforcement Proceedings", submitted for discussion on April 29, 2020 on the initiative and with the financial support of the EU Pravo-Justice Project. It has been found that the principles of the enforcement proceedings are divided on general and specific but the lack of law articles that specify their media art according to the specific implementation of the enforcement proceedings is not conducive to

${ }^{1}$ Candidate of Juridical Sciences (Ph.D), Associate Professor,

Yuriy Fedkovych Chernivtsi National University, Ukraine

ORCID: https://orcid.org/0000-0003-4882-1038 
a proper understanding and enforcement of these standards as fundamental. Special principles are designed to reflect the specifics of this particular area of activity. It is proposed to supplement Art. 2 of the Law Ukraine "On Enforcement Proceedings". Special principles of enforcement proceedings "predictability", "predictability", "efficiency", "cooperation between the parties", "ban procedural abuse", "expertise (professional) artists", which are defined in the Recommendation Rec (2003) 17 as mandatory, and the new principle of "the right to professional legal assistance". It is not recognized perfect for the principles of enforcement procedure proposed by the authors of the law; a proposal to introduce a new principle of "state language of enforcement proceedings" has been received; subjected to criticism of the principle of "confidentiality of information that has a place in the enforcement proceedings" as such that is not related to the protection of confidential information in enforcement proceedings.

The study has been conducted to promote understanding of the principles of enforcement proceedings and provide suggestions of changes and additions to legislation on issues of enforcement proceedings will serve as a guideline for the development of high-quality legislation.

\section{Introduction}

Proper enforcement of a judgment is considered a matter of central importance. The effectiveness of judicial protection and the authority of the government depends not only on the legality and reasonableness of judicial acts or acts of other bodies and persons, but also on how quickly and realistically their implementation will take place. The constitutional right to judicial protection may be exercised when a citizen or organization that has applied to the competent authority for protection of the violated or disputed right has actually received what has been awarded to it.

In Ukraine, the enforcement system has significant problems. A huge number of court decisions simply lies and falls to the dust on the shelves of the State Enforcement Service, and the work of state executors remains unsatisfactory. There are many reasons for this situation. Some of them are listed under the supervision of the Committee of Ministers of the Council of Europe: the budgetary and financial requirements of regulations are too complicated, which do not allow for the provision of existing and possible liability for a court decision; complex and formalized procedures for 
initiating the execution of a court decision on the debts of the state, state enterprises, institutions and organizations; excessive discretionary powers of state executors and other bodies that implement payments under court decisions or take action on them, etc. [25].

Therefore, among the main directions of reforming the system of the judiciary, the judiciary and related legal institutions, the state has identified the need to reorganize the system of enforcement of court decisions and increase the efficiency of enforcement proceedings. The strategy of reforming the judiciary and related legal institutions in 2015-2020 approved by the Decree of the President of Ukraine No. 276/2015 dated May 20, 2015 , it was envisaged to increase the efficiency of justice by ensuring the reorganization of the system of execution of court decisions and increase the efficiency of enforcement proceedings by reducing the formalization and optimization of stages of enforcement proceedings and terms of enforcement actions [41].

Adoption of the new legislation on enforcement proceedings during 2015-2017 was the beginning of the formation of the domestic institution of enforcement of court decisions on a fundamentally new basis. In 2016, Ukraine created a new legal framework for timely, full and impartial enforcement of court decisions and formed a combined (mixed) system of enforcement of decisions of jurisdictions, which provides for a combination of state executive service and private enforcement agents. In May 2020, on the initiative and with the financial support of the EU Pravo-Justice Project, another draft Law of Ukraine "On Enforcement Proceedings" [46] (hereinafter - the Draft Law) was presented to the public for discussion, which proposed to combine two components of enforcement proceedings into one Law. This event confirms the relevance of issues related to the process of enforcement proceedings including a comprehensive study of the principles of the enforcement process and the organization of bodies and persons carrying out enforcement proceedings.

Normative consolidation of the principles of enforcement proceedings has always attracted the attention of researchers because the initial provisions expressed in the rules of law enshrine the essence, content and key ideas of enforcement proceedings. In the works of O.B. Verba-Sidor and S.E. Fedik, O.M. Hryshko, R.S. Kalinin, V.A. Kroytor, P.V. Makushev and O.V. Lyaskovets, M.M. Malskyi, S. Ya. Fursa and others, the principles 
of enforcement proceedings have been studied separately from the principles of organization and activity of the executive service in Ukraine. This is explained by the scientific discussion on the nature of enforcement proceedings, its role and place in the mechanism of human rights protection and in civil proceedings and the identification of several approaches to this issue: 1) the assignment of enforcement proceedings to administrative law and process (S.Ya. Fursa, S.V. Shcherbak [4, p. 31-33]); 2) as a separate branch of law (Yu.V. Bilousov, V.V. Yarkov [51, p. 53]); 3) as part (stage) of the trial (civil, commercial, administrative) (V.V. Komarov, O.V. Hetmantsev, L. Talan, V.A. Bihun, S.V. Vasiliev, V.M. Prytuliyak $[33$, p. 40]); 4) as the last law enforcement cycle of civil proceedings (O.V. Tkachuk [47, p. 217-219]). The existence of the discussion is due to the fact that the legislation of Ukraine contains opposite rules that determine the place of enforcement proceedings in the structure of both civil and other types of proceedings; and the legislative regulation of the organization and activity of the executive service and the process of executive proceedings is carried out by various acts, in which some norms are duplicated, but their content is not disclosed, and others do not correspond to each other at all. In particular, in the current legislation of Ukraine on enforcement proceedings there are no articles that would disclose the content of the principles of enforcement proceedings, and only their list is given.

In the Draft Law, in addition to the codification of enforcement proceedings, in Art. 2. "Principles of Enforcement Proceedings", in contrast to the current legislation, instead of nine, eight updated principles of enforcement proceedings are proposed. However, again, there are no articles that would reveal their content. Obviously, this state of affairs should not take place both from a doctrinal and a legislative point of view, it creates conflicts in the development, implementation and enforcement of legislation on enforcement proceedings.

The success of the implementation of the requirements of the executive document depends not only on the clarity of the requirements formulated in it but also on the extent to which the participants in the enforcement proceedings will adhere to the principles of enforcement proceedings. Therefore the study has two common goals. The first goal is to recognize the shortcomings of the legislative formation of the list of principles of enforcement proceedings. The second purpose of this study is to make 
concrete proposals for realistic changes and additions to the legislation that can be applied now without waiting for future criticism of the practice of application of laws on enforcement proceedings due to the imperfection and inaccuracy of their rules.

Our research will contribute to the understanding of the principles of enforcement proceedings and will serve as a guide for the development of quality legislation on enforcement proceedings.

\section{Sources of the principles of enforcement proceedings}

In the process of learning about enforcement proceedings, it is important to consider the basic principles of construction and operation of this institution. This will allow a deeper understanding of the essence, content and purpose of enforcement proceedings, as well as those that permeate the entire system and determine the nature of the idea and position that form the foundation, the foundations of its construction, existence and functioning. The principles of enforcement proceedings are not always clearly formulated in legal norms and objectified in legislation. However, their understanding and application as a source of law allows to ensure the legal regulation of public relations in case of gaps in current legislation. The guidelines for enforcement applicable to civil (including commercial, consumer, labor and family disputes) and noncustodial criminal cases, other cases of enforcement, and other judicial and non-judicial enforcement acts are enshrined in Recommendations Rec (2003) 17 of the Committee of Ministers of the Council of Europe to member states on enforcement, adopted by the Committee of Ministers on September 9, 2003 at the 851st meeting of the Ministers' Deputies [36], and, in the case of administrative matters, in Recommendation Rec (2003) 16 of the Committee of Ministers of the Council of Europe to member states on the enforcement of administrative and administrative decisions and the annex to this Recommendation [35]. According to these documents, the principles are divided into two areas: those that should be inherent in the enforcement procedure (that is the order of enforcement of court decisions, as well as other executive documents of judicial and other jurisdictions, in accordance with the law) and those that should determine the legal status of enforcement officials. Such a division of the principles of enforcement of decisions is inherent in the Ukrainian law. 
Thus, in Art. 2 of the Law of Ukraine "On Enforcement Proceedings" there are enshrined nine principles of enforcement proceedings, and Art. 4 of the Law of Ukraine "On Bodies and Persons Enforcing Judgments and Decisions of Other Bodies" enshrines nine principles of the state executive service and private executors, however, these Laws do not contain articles that would disclose the content of these principles and principles.

The analysis of the specified normative-legal acts testifies to the specific approach of the legislator both to fixing of a category "principles of executive proceedings", and to its list. In Art. 2 of the Law of Ukraine "On Enforcement Proceedings" (hereinafter - the Law No. 1404-VIII) stipulates that the principles of enforcement proceedings are: the rule of law; binding execution of decisions; legality; dispositivity; fairness, impartiality and objectivity; publicity and openness of enforcement proceedings; reasonable terms of enforcement proceedings; comparability of enforcement measures and the scope of requirements for decisions; ensuring the right to appeal against decisions, actions or omissions of state executors, private executors [46].

At the same time, Art. 4 of the Law of Ukraine "On Bodies and Persons Enforcing Judgments and Decisions of Other Bodies" (hereinafter - the Law No. 1403-VIII) includes among the foundations of the internal affairs bodies and private executors: the rule of law; legality; independence; fairness, impartiality and objectivity; binding execution of decisions; dispositivity; publicity and openness of enforcement proceedings and its recording by technical means; reasonable terms of enforcement proceedings; comparability of enforcement measures and the scope of requirements for decisions [45].

At once two questions arise: 1) why in the Law No. 1404-VIII is the category "principles" used, and in the Law No. 1403-VIII the category "foundations" is applied ?; 2) why does the legislator provide a non-identical list of starting points? Apparently, in order to distinguish "enforcement proceedings" from the "legal status of the subjects of this activity", and used in the first case the concept of "principles", and in the second "principles".

In dictionaries, the term principle is interpreted as the initial, main position, principle [5, p. 325]; the basis of ways and methods of carrying out any activity [1], and the concept of "principles" is defined as follows: guiding ideas that express the most important aspects and content of legal relations and only inherent in them [26, p. 85], "the first principle, the beginning" [28]. 
L.V. Krupnova states that the term "principles" and "foundations" are not the same, at the same time, they should not be opposed, because the principles are more than the foundations. This is due to the fact that the principles reflect the original ideas of legal regulation, and the foundations are the concretized expression of these ideas. Therefore, it would be more logical to apply the concept of "foundations" in the legislative act that determines the legal status of authorized bodies and persons enforcing jurisdictional decisions" [18]. Thus, according to the researcher, the legislator probably decided to distinguish executive activity from the legal status of the subjects of this activity, and applied in the first case the concept of "foundations" and "principles" in the second. And as the list of items in the above article is almost identical, L.V. Krupnova reasonably believes that in both cases you need to use the term "principles" that will make the terminology of the legislation on enforcement proceedings consistent and unified.

In addition, it should be noted that the principles of the enforcement procedure and those relating to the legal status of enforcement officers are set out in one EU document, Recommendation Rec (2003) 17 of the Committee of Ministers of the Council of Europe, and are referred to as "principles".

As I.H. Frantsuz fairly notes "the principles of activity of any state bodies and their officials determine the direction and serve as a starting point for the relevant activity". In addition, the principles of the subjects of enforcement of court decisions set the tone not only for such activities, but also serve as an important basis for the formation of new or improvement of existing legislation in this area [9, p. 68].

Thus the principles of enforcement proceedings reveal the conceptual idea (purpose) and establish the foundations of the mechanism of enforcement of jurisdictional decisions on the basis of which the formation of both relevant legislation and practice.

\section{Legislatively defined principles of enforcement proceedings.}

The principle of the rule of law (paragraph 1, part 1 of Article 4 of the Law No. 1403-VIII and paragraph 1, part 1 of Article 2 of the Law No. 1404-VIII). The rule of law in the context of Art. 8 of the Constitution of Ukraine provides for the supreme legal force of the Constitution of Ukraine and compliance with the laws of Ukraine and other regulations. State 
executors must be guided by the principle of the rule of law in their activities. In this approach, the principle of the rule of law coincides with the principle of legality [40, p. 121-122], D. Sibilov says and prof. P.M. Rabinovych quotes and distinguishes among the properties of the characteristics of the phenomenon of "rule of law" the following: recognition of the priority, dominance, the determining role of human rights in the activities of the state.

The principle of the rule of law in enforcement proceedings is defined as strict observance of the rights and freedoms of the debt collector, debtor and other participants in enforcement proceedings, administrative and judicial appeals by subjects of enforcement proceedings of decisions, actions or omissions of state executors and other officials of the State Enforcement Service [10, p. 38], and as a defining principle of civil service reform, which requires the subordination of state institutions to the needs of human rights, ensuring their priority over all other values of a democratic state [3, p. 7].

The principle of binding execution of decisions (paragraph 5, part 1 of Article 4 of Law No. 1403-VIII and paragraph 2, part 1 of Article 2 of Law No. 1404-VIII) is a component of the principle of the rule of law. $\mathrm{H}$. Z. Ohneviuk notes that the principle of legal certainty is manifested not only in the definition clarity of the law, but in the course of its enforcement of which is its use in resolving disputes, and since the judgment acquires the features of general validity both for the parties process, and for state bodies and the court that made such a decision, its non-compliance levels all the activities of law enforcement agencies, the court, harms human rights, violates the existing law and order, and therefore violates the principle of venstva law in general and the principle of legal certainty while providing binding judgment [29, p. 172]. Therefore, O.M. Hryshko proposes to remove it from the legislation [12, p. 42] in order to eliminate additional duplication.

The principle of legality (paragraph 2, part 1, Article 4 of Law No. 1403-VIII and paragraph 3, part 1, Article 2 of Law No. 1404-VIII), according to which all public authorities and local governments their officials are obliged to act only on the basis within the powers and in the manner provided by the Constitution and laws of Ukraine (Article 19 of the Basic Law of Ukraine). That is public authorities and officials in carrying out their activities developing and making decisions do not have the right to go beyond their competence; and in exercising control and supervision over 
the legality of the actions of participants in public relations must follow legal procedures use legal methods and techniques [42, p. 453], - emphasizes O.Ye. Hida. S.Ya. Fursa and S.V. Shcherbak emphasize the universal obligation to strictly adhere to the principle of legality in the activities of all state bodies, including the activities of the state executor [11, p. 81]. This clearly applies to the activities of a private performer. In addition, according to the principle of legality, which is formulated both in the Constitution of Ukraine and in sectoral legislation, executive legislation must be clear and have a system in place. It is no accident in paragraph " $b$ " of Art. 1 of Section III of Recommendation Rec (2003) 17 states that legislation should be sufficiently detailed to enforce the enforcement procedure with legal predictability and transparency as well as predictability and efficiency [36].

The principle of dispositivity (item 6 part 1 of article 4 of the Law No. 1403-VIII and item 4 part 1 of article 2 of the Law - 1404-VIII). In the theory of law, the principle of dispositivity is defined as a legally established by the state measure of possible lawful conduct of legal entities in the variant use of rights and freedoms, as well as the application of legal provisions in relation to specific life situations [43, p. 63]. The principle of dispositivity in enforcement proceedings determines the ability of persons involved in the case (especially the parties) to dispose of their substantive and procedural rights means of their protection. This possibility is aimed at the emergence development of the process its transition from one stage to another and ultimately to its termination. In enshrining this principle, the legislator primarily has meant the possibility of voluntary execution of the decision by the debtor when the debtor can comply with the decision of the jurisdiction voluntarily and thus avoid enforcement proceedings. However, in enforcement proceedings this principle will be relevant for the claimant. For example, a debt collector may not enforce a writ of execution. The manifestation of the principle of dispositivity is that the executive document as a general rule is issued to the debt collector who independently decides on the expediency and the moment of its application for execution. Also it is possible to achieve conciliation of the parties to the lawsuit by the court approving an amicable agreement, etc. The manifestation of dispositivity is that the parties themselves have the right to apply to the court that issued the document with a request to postpone or installment of its execution as well as to change the method and procedure of execution. The executor also has 
the right to postpone or suspend enforcement actions and the application of enforcement measures at the request of the claimant or on its own initiative, etc. The manifestation of the principle of dispositivity is the participation in enforcement proceedings of representatives of the parties, including a lawyer.

The principle of justice, impartiality and objectivity (paragraph 4, part 1 of Article 4 of the Law No. 1403-VIII and paragraph 5, part 1 of Article 2 of the Law No. 1404-VIII). Examining the principle of fairness, S.P. Pohrebniak cites the classification of rights to a fair trial formed by O.I. Rabtsevich, who attributed the "right to enforce a court decision" to the "rights exercised after consideration of the case on the merits" and notes that natural justice consists in observance of procedural rules and guarantees of procedural rights of the person. These classic requirements of procedural law reduce the likelihood of arbitrariness of power, and it is clear that a decision cannot be recognized as fair when it is taken in a process that does not meet these requirements [32, p. 67-69]. That is the principle of fairness in the enforcement process should ensure the real participation of persons in the process, equality of the parties and reasonable time for execution of the decision. Then S.P. Pohrebniak introduces the idea of formal justice, which, according to D. Lloyd, implies three interrelated concepts: 1) there should be rules that indicate how to treat people in specific cases; 2) these norms must be general in nature, provide that any person who falls under their action must comply with them; 3) these general norms must be applied impartially - without concessions, discrimination and exceptions [32, p. 49]. The main sources of law are an important means of ensuring formal justice. With regard to enforcement proceedings, justice is embodied in the relevant legislation and discloses the nature of procedural activities for the enforcement of judgments and decisions of other bodies.

Fair application of legal norms is first of all a non-discriminatory approach impartiality, which is ensured by the independence of the state executor and consists, first of all, incoherence in their independence by any circumstances and other will than law.

According to Art. 4 of Section IV of Recommendation Rec (2003) 17, enforcement officers must be honest and competent in the performance of their duties and always act in accordance with recognized high professional and ethical standards; they must be impartial in their relations with the 
parties [36]. Based on this wording, we can state that in this way the status principle of objectivity of employees is formulated as well as private executors responsible for the enforcement of the decision. Objectivity in the enforcement of a court decision is that the person carrying out such enforcement must carry out enforcement measures remotely, despite personal preferences or benefits ensuring equal treatment for all participants in enforcement proceedings. Article 6 of Section IV of Recommendation Rec (2003) 17 states that enforcement officers should be subject to disciplinary, civil and/or criminal liability in the event of suspected abuse of office and if their guilt is proven, apply appropriate sanctions to them [36].

Only the existence of clearly formalized algorithms of activity (job descriptions, legislation), which detail the procedure and sequence of actions of the authorized body or person can bring the objectivity of the activity to the appropriate but not ideal level. In this sense, objectivity is very similar to impartiality, L.V. Krupnova says, and the difference between these categories is that the basis of objectivity is consciousness and motivation, the basis of impartiality. The difference between these principles is that objectivity is an indicator of the absence of influence of the other party on the authorized body or person and impartiality is an indicator of the absence of illegal will of public or private performers [18, p. 65].

The principle of independence (paragraph 3, part 1, article 4 of the Law No. 1403-VIII) means the ability to act without any restrictions, influence, pressure, threats, direct or indirect intervention of any authorities [50, p. 42]. "In the traditional sense, independence as a principle presupposes the exercise of powers by the subject of any public authorities, public associations, individuals or legal entities independently, the existence of a ban on interfering in the work of public authorities or obstructing their activities" [13, p. 55], S.O. Ivanytskyi notes. Also the principle of independence is ensured by the presence of the institution of withdrawal and self-withdrawal of the executor.

The principle of publicity and openness of enforcement proceedings (paragraph 6 part 1 of Article 4 of the Law No. 1404-VIII) and its fixation by technical means (paragraph 7 part 1 of Article 4 of the Law No. 1403-VIII). Publicity and openness of enforcement proceedings and their recording by technical means are integral principles of enforcement of jurisdictional decisions, which provide awareness of the progress and 
results of enforcement of jurisdictional decisions, which is perceived and, if necessary, evaluated by society or the state represented by authorized bodies and officials.

The preamble to Recommendations Rec (2003) 17 recommends to take into account the importance of information technology for the implementation of enforcement proceedings and relevant Council of Europe legal instruments, including Recommendation Rec (2003) 14 on the interoperability of justice information systems and Recommendation Rec (2003) 15 on electronic archiving documents in the legal field [36].

Publicity of enforcement proceedings, according to A.I. Perepelytsia, is manifested in the fact that enforcement of decisions of courts and other nonjudicial bodies is carried out in all countries openly, if it does not concern the private life of people [31, p. 110]. In fact, publicity is determined by it through the category of "openness", O. Naumenko also believes that the principle of publicity means openness of enforcement proceedings to the parties, other persons involved in it, persons involved in enforcement actions, and the general public [27, p. 99]. But similarity does not mean identity. Publicity characterizes the process of enforcement of decisions and openness means the availability of information about this activity. Recording of enforcement proceedings by technical means is an auxiliary tool for the implementation of the principles of publicity and openness as it reflects the activities of executors in the form of specific information that is stored on appropriate media and expressed in a perceptible form. Such fixation takes place through an automated system of enforcement proceedings, free access to which is provided by the Ministry of Justice of Ukraine on the Internet on its official website with the ability to view, search, copy, and print information based on common web browsers and editors, without the need to use specially created technological and software tools with no restrictions and around the clock.

A logical question arises: why "fixation by technical means" is not part of the principle of publicity and openness of enforcement proceedings Law 1404-VIII, which regulates the registration of enforcement documents in the automated system of enforcement proceedings, and provides for a Unified State Register of Debtors. associated with fixation by appropriate technical means. It seems logical for paragraph 6 of Part 1 of Art. 4 of the Law No. 1404-VIII and item 7 of part 1 of Art. 4 of the Law No. 1403-VII 
to state in a single wording "publicity and openness of enforcement proceedings and its full recording by technical means" taking into account that the principles of enforcement proceedings and the principles of activity of bodies and persons carrying it out are absolutely equivalent

Reasonableness of the terms of enforcement proceedings (paragraph 8 , part 1 of Article 4 of the Law No. 1403-VIII and paragraph 7, part 1 of Article 2 of the Law No. 1404-VIII) is a certain period of time sufficient for the implementation of a separate stage of enforcement proceedings of an executive action decision-making by an authorized body or person. It should be noted that in Art. 13 of the Law No. 1404-VIII a deadline, within which enforcement proceedings must be completed (all necessary enforcement actions have been taken), does not set. And the lack of clear criteria for such a definition creates a potential risk of violating reasonable time limits for enforcement proceedings. Therefore most scholars compare "reasonable time of enforcement proceedings" with "reasonable time of court proceedings." According to the study, O.M. Hryshko concluded that the Ukrainian scholars approach a reasonable time for consideration of a case/trial as the shortest total time for the preparation and consideration of cases in court (regardless of the type of process) which would ensure a fair, impartial and timely resolution of the case in order to protect violated, undefined or disputed rights, freedoms/interests of individuals/legal entities or the interests of the state without unreasonable delays taking into account the complexity of the case behavior persons involved in it and other factors that determine the timing of cases [12, p. 51]. And in the category of "reasonable time for trial" the scientist identified at least two procedural deadlines - a reasonable time for consideration of the case and a reasonable time for enforcement proceedings [12, p. 53].

We consider this position of O.M. Hryshko quite justified because the practice of the European Court of Human Rights has proved that the execution of a court decision is part of the trial. In particular according to the judgment of the European Court of Human Rights in the case "Hornsby v. Greece" dated March 19, 1997 (Case of Hornsby v. Greece) the execution of the judgment rendered by the court is considered as part of the trial for the purposes of Art. 6 of the Convention for the Protection of Human Rights and Fundamental Freedoms [8], and according to the findings of the case "Burdov v. Russia" dated May 07, 2002 (Case of Burdov 
v. Russia) unreasonably long delay in enforcement, which came into force the violation of the Convention [6].

The principle of proportion coercive enforcement requirements and scope for decisions (p. 9 h. 1 Art. 4 of the Law number 1403-VIII and p. 8 h. 1 Art. 2 of the law number 1404-VIII) R.A. Maidanyk identifies with the proportionality activities of public authorities, according to which they may not "impose on citizens obligations that exceed the limits of necessity arising from the public interest for the purposes to be achieved through the applied measure (or actions of public authorities). Accordingly, the measure applied must be proportionate (must meet) the objectives" $[20$, p. 114]. The proportionality of measures of enforcement of decisions and the scope of requirements for decisions reflects the proportionality of executive and administrative influence and obligations of the debtor to the debt collector and the state. And according to I.H. Frantsuz "the action of this principle contributes to the protection of the rights of the debtor and is that the choice of enforcement of court decisions, defined in Art. 10 of the Law "On Enforcement Proceedings" should be determined by the scope of the requirements of the court decision. That is the implementation of this principle will prevent, says the application of such a measure of enforcement of court decisions as the application for recovery of real estate of significant value when the court decision the debtor must return to the other party a small amount of money [9, p. 83]. After all, a proportionate restriction of human rights and freedoms to achieve public goals cannot impose on citizens obligations that exceed the limits of necessity that follow others. public interest in order to achieve the objectives to be achieved through the measure applied (or the actions of the authorities) and accordingly the measure applied must be proportionate (meet) the objectives [21, p. 16], sums up R.A. Maidanyk.

Paragraphs $g$ and $h$ of Part 1 of Section III of Recommendation Rec (2003) 17 emphasize the consideration of the interests of all parties to enforcement proceedings as well as third parties. If enforcement proceedings concern family law disputes the interests of family members should be taken into account; in addition, if in particular children's rights are affected in accordance with international and national law, the best interests of a child shall be a primary consideration; it is necessary to ensure the protection of certain property and income of the defendant such as basic household goods 
basic types of social assistance funds to meet basic medical needs and the necessary means of employment [36].

This principle is related to another principle of enforcement proceedings humanism, the essence of which are such social values as freedom, equality, justice [4, p. 19], Y.V. Belov fairly remarks. The direction of this principle is that in enforcement proceedings in any form it is prohibited to encroach on the rights, freedoms and interests of individuals the rights and interests of legal entities participating in it.

Thus, this principle is similar to the principles of fairness and proportionality and in enforcement proceedings characterizes the balance between coercion and regulatory requirements between public and private interests. In the studied aspect, "proportionality" should be considered as requirements to limit the decisions of performers (public and private) to the goal to be achieved the conditions of its achievement as well as the obligation to consider the consequences of their decisions, actions and inactions.

The principle of ensuring the right to appeal against decisions, actions or omissions of state executors, private executors (paragraph 9, part 1 of Article 2 of Law No. 1404-VIII) is a logical continuation of the general constitutional principle, according to which everyone is guaranteed the right to appeal in court actions or inaction of public authorities local governments officials (Part 2 of Article 55). In particular, according to Part 1 of Art. 19 of the Law No. 1404-VII, the parties to the enforcement proceedings and the prosecutor as a participant in the enforcement proceedings have the right to appeal against the decisions, actions or omissions of the executor in the manner prescribed by this Law. Also, Art. 74 of the Law No. 1404-VIII clearly stipulates that decisions, actions or omissions of the executor and officials of the state executive service on the execution of a court decision may be appealed by the parties other participants and persons to the court that issued the executive document in the manner prescribed by law. Decisions actions or omissions of the state executor may also be appealed by the debt collector and other participants in the enforcement proceedings (except for the debtor) to the head of the department, to which the state executor is directly subordinated. Decisions actions and inaction of the head of the department, to which the state executor is directly subordinated, may be appealed to the head of the body of the state executive service of the highest level [46]. 
In summary, we note that the principles of enforcement proceedings and the activities of the State Enforcement Service and private enforcement agents in Ukraine work closely with each other and are conditioned by each other, ensuring the implementation of these activities in accordance with generally accepted democratic standards embodied in constitutional provisions and detailed at the legislative level.

\section{Special principles of enforcement proceedings}

The Laws of Ukraine "On Enforcement Proceedings" and "On Bodies and Persons Enforcing Judgments and Decisions of Other Bodies" combine both general and special principles that reflect the specifics of this particular area of activity. General principles of enforcement proceedings significantly prevail over special ones. At the same time, special principles of enforcement proceedings by volume are clearly insufficient, and this conclusion is confirmed by numerous works of such scientists as: S.Y. Fursa, S.V. Shcherbak, V.M. Prytuliak, L.V. Krupnova, V.V. Komarov, M.M. Malsky [24], P.V. Makusheva [22] and others who studied the following special principles: "individual decision-making in specific enforcement proceedings", "binding requirements of the executor", "full execution of the decision", "immediacy of enforcement activities", "compulsory protection of property and interests of the claimant", "indirectness of enforcement of decisions", "authorized state coercion", "inviolability of the minimum property necessary for the existence of the debtor-citizen and members of his/her family", etc.

It should be noted that the legislator ignored such special principles of enforcement proceedings as: "predictability", "predictability", "efficiency", "cooperation of the parties", "prohibition of procedural abuse", "competence (professionalism) of executors", defined in Recommendation Rec (2003) 17 as mandatory. Let us consider them briefly.

The principle of "anticipation" answers the question: to what extent is state intervention permissible within a democracy? This principle requires that the "law" allow everyone to anticipate the consequences of taking an action. It is impossible to anticipate them with absolute certainty. Because a law conferring discretionary powers may meet the requirement "provided by law" in itself provided that the scope of these discretionary powers and the manner, in which they are exercised, are spelled out with 
sufficient clarity to provide adequate protection against arbitrariness" [7] (paragraph 31 of the judgment of the European Court of Human Rights of 27 March 1996 in Goodwin v. The United Kingdom (No. 17488/90)). Thus, the principle of enforceability of "anticipation" means that private interference should be limited to necessary cases and at the minimum level and when carrying out enforcement actions based on an assessment of the facts and circumstances of each enforcement proceedings the executor must anticipate the consequences that may cause his/her specific actions

The principle of "predictability" requires that "legal norms be clear and precise, aimed at ensuring constant predictability of situations of legal relations that arise" [49] (paragraphs 41, 46 of the Report). Predictability means that the law should, where possible, be made public before its implementation and be predictable in terms of its consequences. That is, it must be formulated precisely enough for a person to be able to regulate his/her behavior [15]. Thus, the principle of predictability in enforcement proceedings relates mainly to legislative policy in this area and the stability of legal norms the lack of frequent amendments to the legislation on enforcement proceedings and the endless reform of the enforcement service in Ukraine.

The principle of "efficiency" should be considered, on the one hand, as the duty of public and private performers to ensure the achievement of the necessary results in solving the tasks assigned to them with optimal use of public and private resources and, on the other-as the state provides material, technical, financial and informational resources for the performance of powers by state executors, including unimpeded and timely access to them by citizens.

Despite the lack of normative enshrinement of the principle of "cooperation of the parties" in enforcement proceedings, it is a consequence of the general principles of law: good faith, reasonableness and justice. This principle manifests the moral and ethical mechanisms of enforcement proceedings, which consist in the inner conviction of all subjects of enforcement proceedings to assist each other in the process of execution of decisions.

The principle of "prohibition of procedural abuse" is considered in two aspects. In the first case, the state must establish a mechanism to prevent cases of abuse of the enforcement procedure by one of the parties, which 
should not be considered as a review of the case. In another case, to provide measures to deter procedural abuses or prevent them [36]. However, the legislation on enforcement proceedings does not set criteria for determining abuses of procedural rights.

Under "abuse of rights in the executive process" O.M. Kuznets understands one of the ways of implementation of the subjects of executive procedural relations of their material and (or) procedural rights contrary to the rights and interests of other subjects of these relations and the principles of justice, reasonableness, good faith for the purpose of obtaining additional moral and (or) material benefit or causing harm to another person (persons) $[19$, p. 3]. Not only the debtor but also the creditor can be the subject of abuse during the execution of court decisions. The legal literature considers situations where the subject of abuse may be a court, which may show some bias on the issue of issuing a writ of execution in the case before him. The question of the possibility of abuse by representatives of the newly established institution of private performers is relevant, which, on the one hand, is possible but, on the other, it will promote competition in the enforcement process and minimize the possibility of abuse of rights by representatives of the state executive service [17, p 124]. In addition procedural abuses can be committed during the examination of the value of property and auctions for the sale of seized property by manipulating the understatement of its value imposing an unjustified ban on certain actions (such as travel bans when travel is business trips and related to the main earnings of a citizen), etc. The purpose of these abuses is aimed at prolonging the process or for other dishonest purposes, and the means of their commission is the use of procedural rights provided by law. Procedural abuses are a factor that destabilizes justice and creates serious obstacles to the execution of the final court decision so the legislation on enforcement proceedings requires appropriate amendments to prohibit the abuse of procedural rights by analogy with the Civil Procedure Code of Ukraine.

The principle of "competence (professionalism) of performers" is directly interrelated with the professional training of performers. At the present stage the executor must have basic psychological, physical, legal and tactical-special training on the enforcement of decisions of jurisdictional bodies. Only a professional is able to resist aggression, psychological pressure from debtors, avoid conflicts or reduce their tension [23] and so on. 
Additional requirements may be imposed on the executors for example they may not be persons who have been dismissed for disciplinary misconduct or persons who do not have legal education. These factors clearly affect not only the level of activity of a particular executor, but also in general the legal relationship in the field of enforcement of court decisions.

The considered special principles of enforcement proceedings will promote efficient and cost-effective enforcement of court decisions and decisions of other jurisdictions. Accordingly, the list of principles of enforcement proceedings set out in Laws 1403 to VIII and 1404 to VIII should be supplemented by those discussed above.

\section{Principles of enforcement proceedings in the Draft Law: expediency of adjustment?}

"Every principle begins with an idea, passes this stage but not all ideas turn into principles remaining in the sphere of everyday or scientific thinking. Will the position of practitioner be reasonable in the process of enforcement, if he/she refers to the idea which does not claim confirmation of real rules of law? It is obvious that the requirement of legal certainty, which are basic for modern law, does not always claim confirmation possibility of applied implementation of some natural legal views" [14, p. 173-174]. Therefore, the principle is characterized by stability in legislation and implementation in practice. However, this does not preclude its evolutionary transformation, namely: adjustment, change or even abolition of some elements.

Considering the proposed principles of legislative regulation of enforcement proceedings in Art. 2 of the Draft Law as amended on April 29, 2020. Their list includes: legality; binding execution of decisions; the state language of enforcement proceedings; dispositivity of enforcement proceedings; impartiality and objectivity of the performer; comparability of enforcement measures and the debtor's obligation specified in the executive document; openness of information for participants in enforcement proceedings; confidentiality of information that takes place in enforcement proceedings [44]. It is not clear for what reasons the authors have excluded the principles of enforcement proceedings from the bill, such as: "Rule of law"; "Justice"; "Reasonable terms of enforcement proceedings"; "Ensuring the right to appeal against decisions, actions or omissions of state executors, private executors" and have not include the principles of: "Anticipation"; 
"Predictability"; "Efficiency"; "Proportionality"; "Cooperation of the parties"; "Prohibition of procedural abuse; Competence (professionalism) of performers", which are defined in international legal acts as mandatory.

In the Constitution of Ukraine, the rule of law is enshrined in Part 1 of Art. 8 as a common law principle recognized and valid in the state. In the decision of the Constitutional Court of Ukraine dated November 2, 2004, it was firstly characterized as the embodiment of justice and not as a set of rules of conduct reproduced in laws or other normative legal acts [37]. "In any case, the principle of the rule of law cannot be equated with the principle of the rule of normative legal acts of the state (laws)" [39, p. 300]. Because "the difference between them is due to the difference in understanding of law and normative and legal acts (laws). The principle of the rule of law is more specific. The rule of law means, first and foremost, the rule of right because not every law is just that. Compliance with the content of the right is another feature of the rule of law as its important indicator" [34, p. 342]. It follows that the authors of the Draft Law make an obvious mistake in not including the principle of the rule of law in the list of principles of enforcement proceedings as well as others.

In Art. 13 of the Law No. 1404-VIII does not set a deadline, within which enforcement proceedings must be completed (all necessary enforcement actions have been taken). Specific deadlines for decisionmaking by executors are provided only for certain actions. The absence of deadlines for enforcement proceedings have been compensated by the presence in the Law No. 1404-VIII of the principle of "reasonable terms of enforcement proceedings". In the Draft Law, this principle is excluded from the list of principles of enforcement proceedings and its absence can hardly be compensated by the presence of Article 54 "Reasonable time for decision-making by executors and enforcement actions in Section IV of the General Principles of Enforcement Proceedings".

With regard to two new principles of enforcement proceedings proposed by the authors of the Draft Law, the principle of "state language of enforcement proceedings" does not cause objections, its content is clear and is to a greater extent disclosed in Art. 60 "Translator" of this bill.

While the principle of "confidentiality of information that takes place in enforcement proceedings" is not disclosed by the Draft Law and is not related to the protection of confidential information in enforcement 
proceedings. In item 3 of part 1 and part 3 of Art. 73 of the Draft Law, it provides for the right of the executor to receive confidential information free of charge during enforcement proceedings from state bodies, enterprises, institutions, organizations regardless of ownership, officials, parties and other participants in enforcement proceedings, including those contained in state databases and registers. At the same time, Art. 7, 20, 35, 36 of the Draft Law operate with another term - "professional secret".

So let us try to find out what is meant by the confidentiality of information that takes place in enforcement proceedings. In the dictionary of S.I. Burns, the word "confidentiality" means secret, trusting [30]. In V. Dahl's explanatory dictionary, a confidential conversation or letter means an open, trusting, unannounced [48]. In the Academic Explanatory Dictionary of the Ukrainian language, the word "confidential" means which is not subject to publicity; trusting, secret" [2]. If you refer to legal dictionaries and encyclopedias, you can find the following definition of "confidential information": (from Latin - trust) - information with limited access containing data that are owned, used or disposed of by individuals or legal entities, and which are the subject of their professional, business, production, banking, commercial, etc. interest. The procedure for access to the system of protection and the level of confidentiality of the relevant information are determined by law or their owners [16]. Hence it seems natural that the issue of ensuring the confidentiality of information received by the performer is closely related to ensuring professional secrecy.

The concept of secrecy does not quite coincide with the concept of confidentiality of information as secrecy also means the legal regime. Secrecy is not just information but its certain state. We hide information because it can adversely affect the motivation of actions behavior and thoughts of other actors. By protecting certain information we, first of all, protect ourselves and our own interests. There is no secret outside these interests. However the fact that the owner takes or does not take measures to ensure the confidentiality of information that constitutes the content of the secret is not the main thing although for many legal secrets it is really important. If the information is kept secret it does not mean the information itself but the state of denial of access to it. Therefore secrecy as a legal phenomenon is a lawful prohibition of access to information unauthorized receipt as well as disclosure or any other use that may cause harm. 
The term "confidential", literally "trusting", in relation to information should be used rather in cases of transfer by its owner to other entities, that is "confidential" - persons who are obliged to "keep it secret" or, in other words, ensure its confidentiality.

The need for this is due to the fact that the owner of the object protected by law and his/her the rights or interests may be threatened as a result of dissemination of information or transfer without his/her consent to third parties. In this case "confidentiality" as a requirement is addressed exclusively to the confidant - a person who has legally gained access to information or by virtue of a direct indication of the law on the need to provide him/her with certain information or at the request of the owner. With regard to the latter, the owner usually has the right to dispose of and control the circulation of information that is confidential including the right to remove restrictions on access to it and make it publicly available. For example, there are several types of secrets that are virtually impossible to classify as "confidential information". This is a personal, family secret, a secret of private life, etc., similar secrets. In all these cases the subject the owner carries out the protection of the secret independently and simply does not pass information to other persons and, therefore, there are no confidants. In the case of communication of this information to other persons as in this case - the executor, they become confidential but the regime of secrecy or information changes. When transmitting information to state bodies, such information is already protected in the mode of official secrecy or its variants (secrecy of civil status records, tax secrecy, etc.); commercial or non-profit organization - is considered as personal data, secrecy of confession, banking secrecy, etc. Thus confidential information becomes in the case of its transfer to a confidant who is obliged by law to ensure its confidentiality primarily in the interests of the owner.

As we can see, the term "confidentiality" as a requirement can be addressed only to the confidant, as a rule, it is provided by law while the owners protect information (restricts access to it) usually voluntarily in their own interests as well as refuse from it. Therefore, it is not surprising that the issue of confidentiality of information received by the executor during the enforcement proceedings is closely related to the issue of professional secrecy.

Thus, the institutions of confidentiality and professional secrecy are the basis of the mechanism of non-disclosure of information obtained by 
the executor in the process of enforcement proceedings, and are defined through such categories as "right", "duty", "principle".

Thus, it is expedient to supplement the Draft Law with a separate article "Professional secrecy during enforcement proceedings", in which to determine the procedure of communications (oral, written, telephone conversations, etc.); storage of information from the performer; a ban on transmitting information to third parties and a ban on third parties requiring thise contractor to provide such information.

The principle of the right to professional legal assistance has not found its place in the current legislation on enforcement proceedings and the Draft Law. The specifics of the lawyer's participation in the trial and at the stage of execution of court decisions differs significantly due to the absence in Part 1 of Art. 2 of the Law of Ukraine "On Enforcement Proceedings" of the principle of ensuring the right to professional legal assistance at the stage of execution of court decisions. Therefore, this type of legal assistance does not apply to enforcement proceedings directly, so the parties of enforcement proceedings have the right to choose between a lawyer and a representative. When choosing between these entities, the party to the enforcement proceedings should take into account that the ordinary representative does not have to be an expert in the field of law or have a legal education. While the lawyer's activity is regulated by the Law of Ukraine "On the Bar and Practice of Law" and the Rules of Advocate Ethics, according to which a lawyer may be subject to disciplinary action for poor quality legal assistance at the stage of execution of court decisions. At the stage of enforcement proceedings, the advantages of a lawyer as a professional representative of his/her client are: 1) possession of appropriate theoretical and practical skills; 2) the presence in his/her arsenal of more legal instruments than the representative; 3 ) endowing its legislation with a special legal status. By exercising his/her legal personality and performing legally significant actions a lawyer promotes the proper execution of court decisions.

In order for the principles of enforcement proceedings to be embodied in a truly functioning of the legal mechanism of enforcement proceedings, they must be enshrined in law. The principles of enforcement proceedings studied by us should not just be listed in the article of the law but should be reproduced in its norms through development and specification taking into account the specifics of enforcement proceedings. Summing up the results of the study we note that the draft law needs to be carefully finalized. 


\section{Conclusions}

Summing up the above, we can conclude the following points.

The principles of enforcement proceedings reveal the conceptual idea (purpose) and establish the foundations of the mechanism of enforcement of jurisdictional decisions, on the basis of which the formation of both relevant legislation and practice is implemented. It has been established that most principles are multifaceted and regulate both the enforcement procedure and the legal status of those responsible for enforcement.

Given that the principles of enforcement proceedings and the principles of activity of bodies and persons carrying it out are equivalent, it is necessary to unify their list and enshrine in one normative act by analogy with Recommendations Rec (2003) 17 “On Enforcement”, which is also proposed in Art. 2 by the authors of the Draft Law "On Enforcement Proceedings", submitted for discussion on April 29, 2020 on the initiative and with the financial support of the EU Pravo-Justice Project.

Unambiguous scientific approaches to the classification of the principles of enforcement proceedings in legal science have not been developed but the expansion and refinement of the list of principles of enforcement proceedings due to the development of society (for example the principle of "full fixation by technical means" due to the development of IT technologies (audio recording, video fixation), the principles of "mandatory enforcement" and "legality" absorbed by the principle of "rule of law").

The principles of enforcement proceedings are divided into general (common law) and special but the lack of articles in the legislation that specify their content according to the specifics of implementation in enforcement proceedings does not contribute to the proper understanding and enforcement of these rules as fundamental. In the legislation of Ukraine on enforcement proceedings, there are no special principles of enforcement proceedings defined in Recommendation Rec (2003) 17 as mandatory. Thus Part 1 of Art. 2 of the Law No. 1404-VIII should be supplemented by the principles: "anticipation", "predictability", "efficiency", "proportionality", “cooperation of the parties", "prohibition of procedural abuse", "competence (professionalism) of executors". The list of principles of enforcement proceedings should be supplemented by a new principle of "the right to professional legal assistance".

The list of principles of enforcement proceedings proposed by the authors of the Draft Law "On Enforcement Proceedings" is not perfect, 
the current principles of "rule of law" have been unjustifiably deleted from it, such as: "Justice"; "Reasonable terms of enforcement proceedings"; "Ensuring the right to appeal against decisions, actions or omissions of state executors, private executors". The proposal to introduce a new principle of "state language of enforcement proceedings" is considered justified. However, the principle of "confidentiality of information that takes place in enforcement proceedings" has been criticized as not related to the protection of confidential information in enforcement proceedings in this bill.

The set of principles of enforcement proceedings forms, determines its quality, and therefore forms the quality of enforcement of a court decision body or person. Therefore the proposed changes and additions to the legislation on enforcement proceedings will serve as a guide for the development of quality legislation. Further the vector of scientific research should be directed not to the theoretical component (which is what most scientific studies are devoted to) but to the practical assessment of the principles of enforcement proceedings for compliance with the European standards and case law of the European Court of Human Rights.

\section{References:}

1. Akademichnyi tlumachnyi slovnyk ukrainskoi movy [Academic explanatory dictionary of the Ukrainian language]. Zasada [Principles]. URL: http://sum.in.ua/s/zasada (accessed 10 May 2020). (in Ukrainian)

2. Akademichnyi tlumachnyi slovnyk ukrainskoi movy [Academic explanatory dictionary of the Ukrainian language]. Konfidentsiinyi [Confidential]. URL:http://sum.in.ua/s/konfidencijnyj (accessed 10 May 2020). (in Ukrainian)

3. Averianov, V. B. (2000). Pryntsyp verkhovenstva prava - vyrishalna zasada reformuvannia derzhavnoi sluzhby [The principle of the rule of law is a crucial principle of civil service reform]. Naukovi zasady reformuvannia derzhavnoi sluzhby v Ukraini. [Scientific principles of civil service reform in Ukraine]. (Ed.) et al. V. B. Averianov. Kyiv: "Iurnaukatsentr", pp. 6-13. (in Ukrainian)

4. Bilousov, Yu. V. (2005). Vykonavche provadzhennia: Navch. posib. [Enforcement proceedings: Textbook]. Kyiv: Pretsedent, 192 p. (in Ukrainian)

5. Busel, V. T. (2004). Velykyi tlumachnyi slovnyk suchasnoi ukrainskoi movy. [Large explanatory dictionary of the modern Ukrainian language]. Kyiv, Irpin: Perun, 1440 p. (in Ukrainian)

6. ECHR cases Burdov v. Russia, no. 59498/00, ECHR 1999-I. URL: http://eurocourt.in.ua/Article.asp?AIdx=493 (accessed 10 May 2020).

7. ECHR cases Goodwin v. The United Kingdom, 27 March 1996, no. 17488/90. URL: https://cedem.org.ua/library/sprava-gudvin-proty-velykobrytaniyi/ (accessed 10 May 2020). 
8. ECHR cases Hornsby v. Greece, 19 March 1997, no. 18357/91. URL: http://zakon2.rada.gov.ua/laws/show/980_079. (accessed 10 May 2020). (in Ukrainian).

9. Frantsuz, I. H. (2018). Teoretyko-pravovi aspekty prymusovoho vykonannia sudovykh rishen v Ukraini [Theoretical and legal aspects of enforcement of court decisions in Ukraine]. Candidate's thesis. Kyiv. (in Ukrainian)

10. Fursa, S. Ya., Shcherbak, S. V. (2002). Vykonavche provadzhennia v Ukraini: navch.posib. dlia vyshchykh navch. zakl. [Enforcement proceedings in Ukraine: textbook. for higher education institutions]. Kyiv: Atika. (in Ukrainian)

11. Fursa, S., Shcherbak, S. (2001). Pryntsypy orhanizatsii ta diialnosti derzhavnoi vykonavchoi sluzhby [Principles of organization and activity of the state executive service.]. Pidpryiemnytstvo, hospodarstvo i pravo [Entrepreneurship, economy and law], no. 8, pp. 81-85. (in Ukrainian)

12. Hryshko, O. M. (2018). Administratyvno-pravovyi status orhaniv ta osib, yaki zdiisniuiut prymusove vykonannia sudovykh rishen i rishen inshykh orhaniv. [Administrative and legal status of bodies and persons who carry out enforcement of court decisions and decisions of other bodies]. Candidate's thesis. Kyiv. (in Ukrainian)

13. Ivanytskyi, S. O. (2014). Pryntsypy orhanizatsii i diialnosti prokuratury ta advokatury: zmist i spivvidnoshennia [Principles of organization and activity of the prosecutor's office and the bar: content and relationships]. Naukovyi chasopys natsionalnoi akademii prokuratury Ukrainy [Scientific journal of the National Academy of the Prosecutor's Office of Ukraine], no. 2, pp. 52-62. (in Ukrainian)

14. Ivanytskyi, S. O. (2017). Teoretychni osnovy orhanizatsii advokatury $v$ Ukraini: pryntsypy ta systema [Theoretical foundations of the organization of advocacy in Ukraine: principles and system]. Kyiiv: Interservis, 800 p. (in Ukrainian)

15. Kalinnikov, O. (2018). Urazheni v harantiiakh [Affected by the guarantees]. Zakon i biznes [Law and business], no. 49 (1399), pp. 08-14 December. URL: https://zib.com.ua/ua/135610-konstituciya_ne_dopuskae_podilu_osib_za_ pravom oskarzhiti pi.html (accessed 10 May 2020). (in Ukrainian)

16. Kostetska, T. A. (1998). Konfidentsiina informatsiia [Confidential information]. Yurydychna entsyklopediia [Legal encyclopedia]. (Vols. 1-6). Yu. S. Shemshuchenko (Ed.). Kyiv, “Ukr. entsykl.” URL:http:/leksika.com.ua/10150608/ legal/konfidentsiyna_informatsiya. (accessed 10 May 2020). (in Ukrainian)

17. Kravtsov, S. O., Boryliuk, Ya. P., Yaskorskyi, M. O. (2019). Okremi aspekty zlovzhyvannia protsesualnymy pravamy u vykonavchomu provadzhenni [Some aspects of abuse of procedural rights in enforcement proceedings]. Yurydychnyi naukovyi elektronnyi zhurnal [Legal scientific electronic journal], no. 6, pp. 121-125. (in Ukrainian)

18. Krupnova, L. V. (2018). Systema vykonavchoho provadzhennia v Ukraini: teoretyko-pravovi ta prakseolohichni aspekty [The system of enforcement proceedings in Ukraine: theoretical, legal and praxeological aspects]. Doctor's thesis. Kyiv. (in Ukrainian)

19. Kuznets, O. M. (2016). Subiekty zlovzhyvannia pravamy u tsyvilnomu ta vykonavchomu protsesakh [Subjects of abuse of rights in civil and enforcement proceedings]. Extended abstract of Doctor's thesis. Kyiv. (in Ukrainian) 
20. Maidanyk, R. (2015). Proportsiinist (spivmirnist) i pravo vlasnosti: doktryny i sudova praktyka. [Proportionality (proportionality) and property rights: doctrines and case law]. Pravo vlasnosti: yevropeiskyi dosvid ta ukrainski realii: zb. dopovidei ta mater. mizhnarod. naukovo-prakt. Konfer. (Kyiv, 22-23 zhovt. 2015 r.) [Property rights: European experience and Ukrainian realities: coll. reports and mater. international. scientific practice. conference. (Kyiv, October 22-23, 2015)], pp. 111-113. (in Ukrainian)

21. Maidanyk, R. (2015). Spivrozmirnist vykonavchoho provadzhennia [Proportionality of enforcement proceedings.]. Visnyk Verkhovnoho Sudu Ukrainy [Bulletin of the Supreme Court of Ukraine], no. 11, pp. 15-16. (in Ukrainian)

22. Makushev, P. V. (2012). Kharakterystyka ta znachennia spetsialnykh pryntsypiv vykonavchoho provadzhennia $\mathrm{v}$ diialnosti DVS Ukrainy [Characteristics and significance of special principles of enforcement proceedings in the activities of the Internal Affairs Ministry of Ukraine]. Aktualni problemy vitchyznianoi yurysprudentsii [Actual problems of domestic jurisprudence], no. 3, pp. 69-75. (in Ukrainian).

23. Makushev, P. V. (2014). Okremi napriamky vdoskonalennia orhanizatsii diialnosti vykonavchoi sluzhby v Ukraini [Some areas of improving the organization of the executive service in Ukraine]. JURNALUL JURIDIC NATTIONAL: TEORIE I PRACTICA. URL: http://www.jurnaluljuridic.in.ua/archive/2014/6/21.pdf (accessed 10 May 2020). (in Ukrainian)

24. Malskyi, M. M. (2014). Pryntsypy vykonavchoho protsesu ta yikh analiz cherez pryzmu praktyky YeSPL [Principles of the executive process and their analysis through the prism of the case law of the European Court of Human Rights]. Naukovyi visnyk Mizhnarodnoho humanitarnoho universytetu. Ser: Yurysprudentsiia [Scientific Bulletin of the International Humanities University. Ser.: Jurisprudence], no. 8, pp. 154-157. (in Ukrainian)

25. Mamchenko N. Otsutstvie sredstv u gosudarstva - ne glavnaya prichina nevyipolneniya sudebnyih resheniy [The lack of funds from the state is not the main reason for the failure to comply with court decisions]. URL: https://sud.ua/ru/news/ publication/143913-otsutstvie-sredstv-u-gosudarstva-ne-glavnaya-prichina-nevypolneniya-sudebnykh-resheniy?fbclid=IwAR2ckr2hRaRarSQzne5JAnnzfU6wEaVpSFCK03ynXDXcncI_5JEnF-ooOGU (accessed 10 May 2020). (in Russian)

26. Marchuk, V. P. (2003). Slovnychok yurydychnykh terminiv: navch. posib. [Glossary of legal terms: textbook]. Kyiv: MAUP, 128 p. (in Ukrainian)

27. Naumenko, O. (2010). Zahalni pryntsypy prymusovoho vykonannia rishen hospodarskykh sudiv [General principles of enforcement of decisions of commercial courts]. Visnyk Kyivskoho natsionalnoho universytetu imeni Tarasa Shevchenka [Bulletin of Taras Shevchenko National University of Kyiv], no. 85, pp. 97-101. (in Ukrainian)

28. Novaya filosofskaya entsiklopediya (Vols. 1-4) [New Philosophical Encyclopedia: in 4 volumes]. V. S. Stepin (Ed.) et al. (2010). Moskva: Myisl. URL: http://enc.biblioclub.ru/Termin/175706 Princip (accessed 10 May 2020). (in Russian)

29. Ohneviuk, H. Z. (2015). Oboviazkovist rishennia sudu yak skladova pryntsypu pravovoi vyznachenosti [Binding of a court decision as part of the princi- 
ple of legal certainty.]. Chasopys Kyivskoho universytetu prava [Journal of Kyiv University of Law], no. 2, pp. 171-175. (in Ukrainian)

30. Ozhegov, S. I. (2011). Slovar russkogo yazyika [Dictionary of the Russian language]. Moskva: Oniks. URL: https://slovarozhegova.ru/word.php?wordid=11814 (accessed 10 May 2020). (in Russian)

31. Perepelytsia, A. I. (2005). Orhanizatsiino-pravovi zasady diialnosti derzhavnoi vykonavchoi sluzhby v Ukraini [Organizational and legal bases of activity of the state executive service in Ukraine]. Candidate's thesis. Irpin. (in Ukrainian)

32. Pohrebniak, S. P. (2008). Osnovopolozhni pryntsypy prava (zmistovna kharakterystyka) [Fundamental principles of law (substantive characteristics)]. Kharkiv: Pravo, 240 p. (in Ukrainian)

33. Prytuliak, V. M. (2016). Povnovazhennia sudu pry prymusovomu vykonanni sudovykh rishen u tsyvilnykh spravakh [Powers of the court in the enforcement of court decisions in civil cases]. Candidate's thesis. Odesa. (in Ukrainian)

34. Rabinovych, P. M. (1998). Verkhovenstvo prava [Rule of Law]. Yurydychna entsyklopediia [Legal encyclopedia]. (Vols. 1-6); Vol. 1. Yu. S. Shemshuchenko (Ed.). Kyiv, "Ukr. entsykl." (in Ukrainian)

35. Rekomendatsii Pro vykonannia administratyvnykh rishen i sudovykh rishen v oblasti administratyvnoho prava Rec (2003). 16 (Komitet Ministriv rady Yevropy) [Recommendations About execution of administrative decisions and court decisions in the field of administrative law dated September 9, 2003 No. Rec (2003) 16 (Committee of Ministers of the Council of Europe)]. URL: https://zakon.rada.gov.ua/ laws/show/994_692 (accessed 10 May 2020). (in Ukrainian)

36. Rekomendatsii shchodo prymusovoho vykonannia Rec (2003) 17 (Komitet Ministriv rady Yevropy) [Recommendations on enforcement dated September 9, 2003 No. Rec (2003) 17 (Committee of Ministers of the Council of Europe)]. URL: https://zakon.rada.gov.ua/laws/show/994_868 (accessed 10 May 2020).(in Ukrainian)

37. Rishennia Konstytutsiinoho Sudu Ukrainy u spravi za konstytutsiinym podanniam Verkhovnoho Sudu Ukrainy shchodo vidpovidnosti Konstytutsii Ukrainy (konstytutsiinosti) polozhen statti 69 Kryminalnoho kodeksu Ukrainy (sprava pro pryznachennia sudom bilsh miakoho pokarannia) vid 2.11.2004 r. [Decision of the Constitutional Court of Ukraine in the case on the constitutional petition of the Supreme Court of Ukraine on the compliance of the Constitution of Ukraine (constitutionality) with the provisions of Article 69 of the Criminal Code of Ukraine (case of sentencing by a court) of 2.11.2004]. Ofitsiinyi visnyk Ukrainy [Official Gazette of Ukraine], 2004, 45, Art. 2975. (in Ukrainian)

38. Shcherbak, S. V. (2013). Vykonavchyi protses v Ukraini: pravova pryroda [Executive process in Ukraine: legal nature.]. Pravovyi visnyk Ukrainskoi akademii bankivskoi spravy [Legal Bulletin of the Ukrainian Academy of Banking], no. 2(9), pp. 30-35. (in Ukrainian)

39. Shevchuk, S. (2007). Sudova pravotvorchist: svitovyi dosvid i perspektyvy $v$ Ukraini [Judicial lawmaking: world experience and prospects in Ukraine]. Kyiv: Referat, 640 p. (in Ukrainian)

40. Sibilov, D. (2012). Pryntsypy zakonnosti ta verkhovenstva prava $u$ vykonavchomu provadzhenni: ideolohichni aspekty yikh realizatsii [Principles of 
legality and rule of law in enforcement proceedings: ideological aspects of their implementation]. Visnyk akademii pravovykh nauk Ukrainy [Bulletin of the Academy of Legal Sciences of Ukraine], no. 1, pp. 118-126. URL: http://nbuv.gov.ua/ UJRN/vapny_2012_1_14 (accessed 10 May 2020). (in Ukrainian)

41. Stratehiia reformuvannia sudoustroiu, sudochynstva ta sumizhnykh pravovykh instytutiv na 2015-2020 roky [Strategy for reforming the judiciary, the judiciary and related legal institutions for 2015-2020]: Ukaz Prezydenta Ukrainy vid 20 travnia 2015 roku [Decree of the President of Ukraine of May 20, 2015]. URL:http://zakon.rada.gov.ua/laws/show/276/2015. (accessed 10 May 2020). (in Ukrainian)

42. Teoriia derzhavy ta prava [Theory of State and Rights]. O. Ie. Hida (Eds.). (2011). Kyiv: FOP O.S. Lipkan. (in Ukrainian)

43. Teoriya gosudarstva i prava: kurs lektsiy. M. N. Marchenko (Ed.) et al. (1996). [Theory of State and Rights: Lecture Course]. Moskva: Zertsalo TEIS. (in Russian)

44. The Draft Law of Ukraine dated April 29, 2020 "About executive proceedings". URL: https://www.pravojustice.eu/storage/app/uploads/public/5eb/141/517/ 5eb141517f791212178476.pdf?fbclid=IwAR3U12IyvYu5jphFwk8CIdwT-jzv-yyw8CBFT3ZGxcA5V9n_nc0Gch9B0WQ (accessed 10 May 2020). (in Ukrainian)

45. The Law of Ukraine dated Juny 2, 2016 No. 1403-VIII "About bodies and persons who carry out enforcement of court decisions and decisions of other bodies". URL: https://zakon.rada.gov.ua/laws/show/1403-19 (accessed 10 May 2020). (in Ukrainian)

46. The Law of Ukraine dated Juny 2, 2016 No. 1404-VIII "About executive proceedings". URL: https://zakon.rada.gov.ua/laws/show/1404-19 (accessed 10 May 2020). (in Ukrainian)

47. Tkachuk, O. V. (2016). Realizatsiia sudovoi vlady u tsyvilnomu sudochynstvi Ukrainy: strukturno-funktsionalnyi aspekt [Implementation of judicial power in civil proceedings of Ukraine: structural and functional aspect]. Doctor's thesis. Kharkiv. (in Ukrainian)

48. Tolkovyiy slovar V. Dalya onlayn [Explanatory dictionary of V. Dahl online]. URL: http://slovardalja.net/word.php?wordid=13747 (accessed 10 May 2020). (in Russian)

49. Verkhovenstvo prava (2011). Venice, 25-26 March. [Rule of Law]. Pravo Ukrainy [Law of Ukraine], no. 10, pp. 168-184. URL: https://www.venice.coe.int/ webforms/documents/default.aspx?pdffile $=\mathrm{CDL}-\mathrm{AD}(2011) 003$ rev-ukr $\quad$ (accessed 10 May 2020). (in Ukrainian).

50. Von, D., Zaretska, I., Madaian, K. (2015). Yevropeiski ta mizhnarodni standarty u sferi sudochynstva [European and international standards in the field of justice]. Kyiv: USAID, 708 p. (in Ukrainian)

51. Yarkov, V. V. (2006). Razvitie grazhdanskogo ispolnitelnogo prana Rossii: kratkiy ocherk. [The development of civilian executive prana in Russia: a brief outline]. UnIversitetskI naukovI zapiski, no. 1(17), pp. 51-70. URL: http://www.univer.km.ua./visnyk/950.pdf. (accessed 10 May 2020). (in Russian) 